\title{
Selected personality characteristics of university students of management
}

\author{
Alena Kajanováa ${ }^{1, *}$, and Michaela Ruso ${ }^{1}$ \\ ${ }^{1}$ Institute of Technology and Business in České Budějovice, Faculty of Corporate Strategy, Okružní \\ 517/10, 37001 České Budějovice, Czech Republic
}

\begin{abstract}
.
Research background: Researching the topic of personality profiles of future managers is one of the international challenges. In a global world, it is ideal to find framework for ideally pursuing this profession. Existing studies indicate rather influences of gender or other socio-demographic factors rather than the study programs of university students.

Purpose of the article: The aim of the paper is to describe selected personality characteristics of university students in management in comparison with a group of students from other fields at the same university. The following characteristics were measured: a) personality profile based on the Big Five in the field of neuroticism, extraversion, openness to change, conscientiousness and friendliness, and then b) locus of control and c) coping strategies.

Methods: Quantitative research was carried out, where a battery of standardized tools was used as a research technique: the standardized NEO-FFI questionnaire describing the above personality traits, the SVF-78 questionnaire measuring coping strategies and the IPC scale questionnaire measuring internal and external locus of control. The questionnaires were administered to a total of 164 management students in České Budějovice (South Bohemian Region).

Findings \& Value added: From the point of view of NEO-FFI, economists differ in the item conscientiousness $(p=0.005 ; \mathrm{F}=4.387)$, which in the case of this field also came out as the most significantly supported characteristic. On the contrary, the property neuroticism was the least represented in the target group. The locus of control of management students differs compared to other fields in the $\mathrm{P}$ dimension $(\mathrm{p}=0.009 ; \mathrm{F}=$ 3.868), so these students believe that their situation is managed by rather influential people. No relationship was recorded within coping strategies across disciplines, positive strategies prevail among students.
\end{abstract}

Keywords: university students; NEO-FFI; personality; coping strategies; locus of control.

JEL Classification: $A 20 ; A 13 ; M 50$

\footnotetext{
*Corresponding author: ali.kajanova@email.cz
} 


\section{Introduction}

The aim of the paper is to describe selected personality characteristics of university students in management in comparison with a group of students from other fields at the same university. We worked with the assumption that differences in these psychological characteristics exist between students across the fields of study. The subject-matter article was published as a part of IGS Project (internal grant competition); Project Number: 8110009, Order Number: 05IRP014; Project Name: Psychological-Entrepreneurial competences of university students at ITB.

\subsection{Psychological characteristics of university students}

Numerous researches focused on the personality of university students exist. We therefore focus solely on those related to the research tools and conceptions we use, namely Big 5, locus of control and coping strategies.

Big 5 is the most frequently used model nowadays. It is a five-factor model, which forms a personality structure and has the following factors: Extraversion, Agreeableness, Conscientiousness, Emotional stability (Neuroticism) and a variously called fifth factor. [1]

Buelow and Cayton [2] tried to examine the relations between the Big 5 personality traits and the performance and have identified the relation between the performance in decision-making tasks and neuroticism, extraversion, openness and conscientiousness. The Big 5 traits are crucial as they are closely related to further psychical characteristics, for example creativity [3] or empathy. Rogowska [4] compared Big-5 personality characteristics between sporting and non-sporting students by means of a NEO-FFI questionnaire. She identified significantly lower neuroticism, openness and agreeableness among sportspeople.

Coping is an effort for the regulation, limitation or overcoming of the internal or external tension resulting from the interaction between the environment and a person, from the cognitive, social and behavioural points of view. Coping can be perceived as a situational or dispositional characteristic or, as the case may be, as the interaction of both. Coping strategies for stress are: coping with stress focused on the problem, focused on the coping with emotions or focused on the escape. Three types of response exist in the instance of ineffective coping with stress: psychological symptoms like depression, fading away, somatic symptoms like stomach ache, headache, or behavioural disorders like alcoholism, smoking or changes in performance. [5]

Sagalakova et al. [6] points out the fact that a young person starting university studies is particularly vulnerable to stress and has the biggest problems to cope with it, which is given by the development relations. Nevertheless, further studies have proven the difference between the fields of study. Law students are more confrontational to a stress situation, psychology students, on the other hand, do not use the searching for social support [7]. Dealing with coping strategies in this population is therefore definitely reasonable. Chovanec and Gropel [8] have identified a change of coping strategies in the positive direction as a subsequence of regular physical exercises of students. Silaeva et al. [9] studied coping strategies of students of the first year and described the "problem solving plan" as the most frequent one (15\%), followed by the "searching for social support" (14 $\%)$, the "self-control" (13\%) and the "positive evaluation" (13\%). They also found differences between studying residents and students from different towns. According to Shields [10] men more often use active coping strategies. 


\subsection{Locus of control}

According to Rotter, human behaviour is influenced by different types of reinforcement, however, the extent and the character of their influence is mediated by internal cognitive factors. The expectation of the consequences of certain behaviour and the relative value of reinforcement in various situations among these factors. Locus of control describes the degree to which an individual is convinced that he/she is able to control the results of his/her activity. People with internal locus of control believe that they themselves influence their lives. Those with external locus of control, on the other hand, believe that all events are affected by influences that are completely out of their control [11].

The impact of personal characteristics on an entrepreneurial intention is a classic topic in the field of business research $[12,13]$. Previous research mostly applied simple linear models, which led to a gap in the mutual relations between personal traits and their systematic influence on entrepreneurial intentions. Sun et al. [14] examined the mutual relation between four specific entrepreneurial characteristics (i.e. need for achievement, locus of control, risk taking tendency and creativity) and their systematic influence on the entrepreneurial intentions of students of technical fields. The research data comes from 210 technology students through a survey. The findings indicate that creativity and risk taking directly affect entrepreneurial intentions, while the need for achievement and the locus of control influence them indirectly. Maadal [15] identified significantly more frequent LOC among men than among women. Garcia-Almeida and Cabrera-Nuez [16] have described the influence of internal LOC on the proactivity of students.

\section{Methods and data}

Quantitative research was carried out, where a battery of standardized tools was used as a research technique: the standardized NEO-FFI questionnaire describing the above personality traits, the SVF-78 questionnaire measuring coping strategies and the IPC scale questionnaire measuring internal and external locus of control. The questionnaires were administered to a total of 164 students Vysoké školy technické a ekonomické in České Budějovice (South Bohemian Region) in full-time and part-time study with an average of 27 years. It was a student of various technical disciplines, of which $56 \%$ were management and we count only this number for the needs of the article. The rest of the respondents consisted of students of technical branches like mechanical engineering, logistics or construction. The data were statistically processed in the SPSS program by means of ANOVA test.

\section{Results}

From the point of view of NEO-FFI, economists differ from other fields of study in the item conscientiousness $(\mathrm{p}=0.005 ; \mathrm{F}=4.387)$, which in the case of this field also came out as the most significantly supported characteristic. On the contrary, the property neuroticism was the least represented in the target group, as Table 1 below shows. 
Table 1. NEO-FFI among management students.

\begin{tabular}{|c|c|c|c|c|c|}
\hline & $\mathbf{N}$ & Minimum & Maximum & Mean & Std. Deviation \\
\hline Neuroticism & 164 & 0.00 & 46.00 & 21.890 & 7.886 \\
\hline Extraversion & 164 & 0.00 & 48.00 & 32.659 & 7.803 \\
\hline Openness & 164 & 0.00 & 44.00 & 25.652 & 6.401 \\
\hline Agreeableness & 164 & 0.00 & 42.00 & 30.421 & 6.346 \\
\hline Conscientiousness & 164 & 0.00 & 48.00 & 33.927 & 6.746 \\
\hline Valid N & 164 & & & & \\
\hline
\end{tabular}

Locus of control in management students differs from that in students of other fields in dimension $\mathrm{P}(\mathrm{p}=0.009 ; \mathrm{F}=3.868)$, i.e. these students are statistically significantly more often convinced that rather powerful people control their situation. Table 2 shows the distribution of the individual IPC items.

Table 2. IPC scale among management students.

\begin{tabular}{|c|c|c|c|c|c|}
\hline & $\mathbf{N}$ & Minimum & Maximum & Mean & Std. Deviation \\
\hline I & 164 & -6.00 & 24.00 & 10.506 & 5.037 \\
\hline P & 164 & -24.00 & 15.00 & -4.592 & 7.090 \\
\hline C & 164 & -20.00 & 17.00 & -1.354 & 7.015 \\
\hline Valid N & 164 & & & & \\
\hline
\end{tabular}

No statistically significant relation has been seen in coping strategies across the fields of study (see Table 4), positive strategies prevail among students in general. Management students are shown in Table 3. As we can see, students reached the highest value in positive self-instruction, control over situation, control over response. The lowest scores were on the other hand reached in resignation and self-blame.

Table 3. SVF assessment among management students.

\begin{tabular}{|c|c|c|c|c|c|}
\hline & $\mathbf{N}$ & Minimum & Maximum & Mean & Std. Deviation \\
\hline undervaluation & 164 & 2.00 & 23.00 & 11.854 & 4.766 \\
\hline blame denial & 164 & 1.00 & 19.00 & 11.067 & 3.096 \\
\hline deflection & 164 & 7.00 & 24.00 & 13.366 & 3.705 \\
\hline substitutive satisfaction & 164 & 2.00 & 24.00 & 11.915 & 4.518 \\
\hline control over situation & 164 & 6.00 & 24.00 & 15.939 & 3.725 \\
\hline control over responses & 164 & 5.00 & 24.00 & 15.756 & 3.475 \\
\hline
\end{tabular}




\begin{tabular}{|c|c|c|c|c|c|}
\hline pos. self-instruction & 164 & 4.00 & 24.00 & 16.238 & 3.751 \\
\hline social support & 164 & 0.00 & 24.00 & 14.305 & 4.979 \\
\hline avoidance & 164 & 3.00 & 24.00 & 15.488 & 4.338 \\
\hline escaping & 164 & 0.00 & 23.00 & 9.976 & 4.291 \\
\hline perseverance & 164 & 2.00 & 24.00 & 13.372 & 5.142 \\
\hline resignation & 164 & 1.00 & 20.00 & 8.323 & 4.068 \\
\hline self-blame & 164 & 0.00 & 24.00 & 9.848 & 4.829 \\
\hline POS & 164 & 6.00 & 19.14 & 13.733 & 2.291 \\
\hline POS1 & 164 & 2.50 & 19.50 & 11.460 & 3.166 \\
\hline POS2 & 164 & 5.50 & 21.00 & 12.640 & 3.370 \\
\hline POS3 & 164 & 5.67 & 22.67 & 15.978 & 3.110 \\
\hline NEG & 164 & 1.00 & 22.25 & 10.380 & 3.754 \\
\hline Valid N & 164 & & & & \\
\hline
\end{tabular}

Table 4. ANOVA test - SVF across the fields of study.

\begin{tabular}{|c|c|c|c|c|c|}
\hline & & df & Mean Square & $\mathbf{F}$ & Sig. \\
\hline \multirow{3}{*}{ POS } & Between Groups & 3 & 8.702 & 1.719 & 0.163 \\
\hline & Within Groups & 272 & 5.062 & & \\
\hline & Total & 275 & & & \\
\hline \multirow{3}{*}{ POS1 } & Between Groups & 3 & 2.263 & 0.234 & 0.873 \\
\hline & Within Groups & 272 & 9.668 & & \\
\hline & Total & 275 & & & \\
\hline \multirow{3}{*}{ POS2 } & Between Groups & 3 & 20.628 & 1.982 & 0.117 \\
\hline & Within Groups & 272 & 10.408 & & \\
\hline & Total & 275 & & & \\
\hline \multirow{3}{*}{ POS3 } & Between Groups & 3 & 20.456 & 2.117 & 0.098 \\
\hline & Within Groups & 272 & 9.661 & & \\
\hline & Total & 275 & & & \\
\hline NEG & Between Groups & 3 & 10.881 & 0.720 & 0.541 \\
\hline
\end{tabular}




\begin{tabular}{|l|c|c|c|c|l|l|}
\hline & Within Groups & & 272 & 15.113 & & \\
\cline { 2 - 6 } & Total & & 275 & & & \\
\hline
\end{tabular}

\section{Conclusion and discussions}

Literature presents that a manager needs certain traits, skills and abilities, which are bound to the specifics of his/her work. These are particularly analytical thinking, intelligence, stamina, integrity, self-confidence and sociability [17]. Our research has only revealed differences in personality traits of managers in comparison to students of technical fields in some aspects. These are particularly higher occurrence of conscientiousness among managers and higher inclination to the feeling of influenceability of the situation by significant others. Conscientiousness and extraversion are two Big 5 traits presented by Cable and Judge [18] as crucial for the influencing of the managerial performance.

Howell and Avolio [19] identified a high internal locus of control in managers, which contradicts our outcomes, where LOC of external type prevailed. According to Forte [20] internal or external locus of control significantly affects the moral thinking of managers and in final consequence also their ethical decision making. Nevertheless, according to Rees [21] significant cultural differences exist in LOC and Czech students can therefore show different values in comparison to foreign ones.

The outcomes of the research can be utilized as a source for a discussion on possible development of students, but also for further scientific purposes in the sphere of knowledge.

\section{References}

1. Hřebíčková, M. (2011). Pětifaktorový model v psychologii osobnosti: př́stupy, diagnostika, uplatnění. 1. Ed. Psyché. Praha: Grada.

2. Buelow, M. T., Cayton, C. (2020). Relationships between the big five personality characteristics and performance on behavioral decision making tasks. Personality and Individual Differences, 160, 109931.

3. O'Tuathaigh, C. M. P., Idris, A. N., Duggan, E., Costa, P., Costa, M. J. (2019). Medical students' empathy and attitudes towards professionalism: Relationship with personality, specialty preference and medical programme. Plos One, 14(5), e0215675.

4. Rogowska, A. M. (2020). Personality differences between academic team sport players and physical education undergraduate students. Physical Education of Students, 24(1), 55-62.

5. Komárová, R., Slaměník, I., Výrost, J. (2001). Aplikovaná sociální psychologie. III., Sociálně psychologický výcvik. 1. Ed. Psyché. Praha: Grada Publishing.

6. Salagakova, O. A., Truyevtsev, D. Y., Stoyanova, I. Y., Teriokhina, O. V., Shukhlova, Y. A., (2016). Social anxiety in adolescence and youth in the context of psychological safety. Voprosy Psikhologii, (6), 63-+.

7. Pilishvili, T., Karabushchenko, N. (2016). Stress Resistance and Viability Features Among First Year Rudn University Students. In L. G. Chova, A.L. Martinez \& I.C. Tores (Eds.), Proceedings of ICERI 2016: International Conference of Education, Research and Innovation (pp. 5874-5874). Seville, Spain: ICERI Proceedings. 
8. Chovanec, L., Gropel, P. (2020). Effects of 8-week endurance and resistance training programmes on cardiovascular stress responses, life stress and coping. Journal of Sports Sciences, 38(15), 1699-1707.

9. Silaeva, A. V., Kornetov, A. N., Moreva, S. A., Luppa, N. A., Obukhovskaya, V. B., Golovkha, N. E., Pryadukhina, N. I. (2015). Factors of resistance to organizational stress among first-year student of a medical university. Sibirskiy Psikhologicheskiy Zhurnal - Siberian Journal of Psychology, (58), 108-120.

10. Shield, N. (2001). Stress, Active Coping, and Academic Performance Among Persisting and Nonpersisting College Students. Journal of Applied Biobehavioral Research, 6(2), 65-81.

11. Plháková, A. (2011). Učebnice obecné psychologie. 1. Ed. Praha: Academia.

12. Caha, Z., Sassmannshausen, S. P., Faltermeier J. F., Justus, X. (2017). Unternehmerische Kompetenzen an Hochschulen für angewandte am Beispiel einer Hochschule in Ostbayern und Südböhmen. Lüdenscheid: RAM-Verlag.

13. Caha, Z. (2016). Analysis of the System of Planning, Management and the Assessment of the Work Performance of the Academic Staff Members. In R. Stefko, M. Frankovsky \& R. Fedorko (Eds.), Management 2016: International business and management, domestic particularites and emerging markets in the light of research (pp. 42-54). Prešov: Bookman s.r.o.

14. Sun, H. Y., Ni, W. B., Teh, P. L., Lo, C. (2020). The Systematic Impact of Personal Characteristics on Entrepreneurial Intentions of Engineering Students. Frontiers in Psychology, 11, 1072.

15. Maadal, A. (2020). The Relationship between Locus of Control and Conformity. Journal of Cognition and Culture, 20(1-2), 100-115.

16. Garcia-Almeida, D. J., Cabrera-Nuez, M. T., A. (2020). The influence of knowledge recipients' proactivity on knowledge construction in cooperative learning experiences. Active Learning in Higher Education, 21(1), 79-92.

17. Jarošová, E., Pauknerová, D., Lorencová, H. (2016). Nové trendy v leadershipu. Praha: Management Press.

18. Cable, D.M., Judge, T. A. (2013). Managers' upward influence tactic strategies: the role of manager personality and supervisor leadership style. Journal of organizational Behaviour, 24(2), 197-214.

19. Howell,J.M., Avolio, B. J. (1993). Transformational Leadership, Transactional Leadership, Locus of Control, and Support for Innovation: Key Predictors of Consolidated-Business-Unit Performance, Journal of Applied Psychology, 78(6), 891902.

20. Forte, A. (2005). Locus of Control and the Moral Reasoning of Managers. Journal of Business Ethics, 58(1-3), 65-77.

21. Rees, G. (2011). Japan: How resilient a nation. Dart Center. Retrieved from: https://dartcenter.org/content/how-resilient-is-japan 